\title{
TINJAUAN PENDEKATAN KOMPRATIF DALAM ANTROPOLOGI HUKUM
}

\author{
OLEH \\ : OKTA WISNU MANGGALA \\ Email \\ :oktawisnu123@gmail.com \\ No Bp \\ : 1910003600215 \\ Perguruan Tinggi : Universitas EkaSakti-AAI Padang
}

\section{A. Pendahuluan}

Antropologi sebagai salah satu cabang ilmu social mempunyai bidang kajian sendiri yang dapat dibedakan dengan ilmu sosial lainnya, seperti sosiologi, ilmu ekonomi, ilmu politik, kriminologi dan lain-lainnya. Antropologi juga dapat dikelompokkan kedalam cabang ilmu humaniora karena kajian nya yang terfokus kepada manusia dan kebudayaannya. Sebagaimana sudah dijelaskan bahwa, secara umum dapat dikatakan antropologi merupakan ilmu yang mempelajari manusia dari segi keragaman fisiknya, masyarakatnya, dan kebudayaannya. Seperti yang pernah diungkapkan Koentjara ningrat bahwa ruang lingkup dan dasar antropologi belum mencapai kemantapan dan bentuk umum yang seragam di semua pusat ilmiah di dunia. Menurutnya, cara terbaik untuk mencapai pengertian akan hal itu adalah dengan mempelajari ilmu-ilmu yang menjadi pangkal dari antropologi,dan bagaimana garis besar proses perkembangan yang mengintegrasikan ilmu-ilmu pangkal tadi, serta mempelajari bagaimana penerapannya di beberapa Negara yang berbeda.

Dalam antropologi terdapat pembagian pembahasan terkait manusia(bermasyarakat) diantaranya perkembangan fisik. Dimana perkembangan fisik tertarik pada sisi fisik dari manusia.Termasuk didalamnya mempelajari gen-gen yang menentukan struktur dari tubuh manusia. Mereka melihat perkembangan mahluk manusia sejak manusia itu mulai ada di bumi sampai manusia yang ada sekarang ini. Beberapa ahli Antropologi Fisik menjadi terkenal dengan penemuan-penemuan fosil yang membantu memberikan keterangan mengenai perkembangan manusia. Ahli Antropologi Fisik yang lain menjadi terkenal karena keahlian forensiknya; mereka membantu dengan menyampaikan pendapat mereka pada sidang - sidang pengadilan dan membantu pihak berwenang dalam penyelidikan kasus-kasus pembunuhan.

Sedangkan ruang lingkup manusia khusus budaya (bermasyarakat) lebih mengarah tingkah laku manusia. Dimana dalam antropologi lebih sering disebut 
Antropologi Budaya berhubungan dengan apa yang sering disebut dengan Etnologi. Ilmu ini mempelajari tingkah-laku manusia, baik itu tingkah-laku individu atau tingkah lakukelompok. Tingkah-laku yang dipelajari disini bukan hanya kegiatan yang bisa diamati dengan mata saja, tetapi juga apa yang ada dalam pikiran mereka.Pada manusia, tingkah laku ini tergantung pada proses pembelajaran. Apa yang mereka lakukan adalah hasil dari proses belajar yang dilakukan oleh manusia sepanjang hidupnya disadari atau tidak. Mereka mempelajari bagaimana bertingkah-laku ini dengan cara mencontoh atau belajar dari generasi diatas nya dan juga dari lingkungan alam dan social yang ada disekelilingnya. Inilah yang oleh para ahli Antropologi disebut dengan kebudayaan. Kebudayaan dari kelompok-kelompok manusia,baik itu kelompok kecil maupun kelompok yang sangat besar inilah yang menjadi objek spesial dari penelitian-penelitian Antropologi Sosial Budaya. Dalam perkembangannya Antropologi Sosial-Budaya ini memecah lagi kedalam bentuk-bentuk spesialisasi atau pengkhususan disesuaikan dengan bidang kajian yang dipelajari atau diteliti.

Itulah sebabnya penelitian antropologis terhadap hukum sebagai salah satu aspek budaya dibedakan menjadi dua kelompok tujuan, yaitu: penelitian untuk kepentingan pengembangan Antropologi, dan penelitian untuk pengembangan Ilmu Hukum. Antropologi Hukum menekankan pada penelitian untuk pengembangan Ilmu Hukum(J.B.Daliyocs : 1992 : 140).

\section{B. Pembahasan}

Antropologi adalah salah satu cabang dalam ilmu sosial yang membahas budayamasyarakat suatu etnis. Antropologi sendirk timbul karena adanya ketertarikan dari orang Eropa yang melihat budaya, ciri-ciri fisik dan adat istiadat yang berbeda. Kata antropologi sendiri sebenarnya berasal dari bahasa Yunani "anthropos" serta "logos".Anthropos sendiri berarti manusia, sedangkan logos berarti ilmu.

Sehingga antropologi bias didefinisikan sebagai suatu ilmu yang mempelajar imanusia menurut keanekaragaman fisik, dan juga kebudayaannya. Sehingga pembagian obyek kajian antropologi merupakan manusia, kebudayaan dan juga perilakunya. Ini yang membuat obyek antropologi bersangkutan dengan semua manusia kapanpun dan dimanapun. Tujuan antropologi sendiri yaitu buat membangun masyarakat dengan cara mempelajari perilakunya.Perilaku dari beberapa factor perubahan social bagaimana manusia bias bermasyarakat dalam suku bangsa dan budaya manusia. Antropologi sendiri sebenarnya ilmu yang memadukan secara integratif serta bertujuan biologi serta sosiobudaya di kehidupan sehari-hari. 
Didalam perkembangan antropologi,masalah hokum sebenarnya juga sudah pernah ditelaah, walaupun di dalam suatu kerangka kebudayaan yang serba luas. Sarjanasarjana antropologi seperti Barton, Radcliffe-Brown, Malinowski dan lainnya, pernah memusatkan perhatian pada hukum sebagai suatu gejala sosial-budaya. Sesudah embrio dari antropologi hokum timbul, maka pandangan parasarjana seperti Schapera,Gluckman, Hoebel, Bohannan, Pospisil, Nader dan lainnya mempunyai peranan besar didalam perkembangan A.H. (Soekanto, 1984: 159-160).

Implikasi pendekatan semacam ini adalah : bahwa hokum memberi input kepada pranata pengendalian social (apapun variant-nya) dan kemudian kepada rujukan berpikir masyarakat, dan sebaliknya. Hukum, disisilain, dapat pula menyebabkan perubahan perangkat berpikir, dan rujukan kemasyarakatan lainnya atau dikenal dalam sosiologi hukum sebagai "law as tool of social engineering". Namun, bila ke semua hal itu berubah (dan pada kenyataannya memang selalu demikian), maka hukum pun berubah mengikuti perubahan masyarakat dan lingkungannya.

Pendekatan antropologi (hukum) sengaja menggeser pusat perhatian dari aturanaturan kepada individu atau manusia sebagai actor yang dalam mengambil keputusan mengenai perilakunya dihadapkan kepada tuntutan - tuntutan dari tatanan hokum yang dihadapinya (Ihromi,2000: 3). Sejalan dengan itu,Spiertzdan Wiber(1979: 3)

Dengan demikian, hukum dalam lingkup kajian Antropologi Hukum (selanjutnya ditulis A.H.) ditanggapi sebagai gejala empirik yang terjadi dalam kehidupan masyarakat. Hukum dalam konteks ini tidak ditanggapi seperti halnya para yuris mengkaji hokum (secaradogmatik).

Pendekatan antropologi adalah salah satu upaya memahami agama dengan cara melihat wujud praktik keagamaan yang tumbuh dan berkembang dalam masyarakat. Antropologi pada hakikatnya membahas mengenai pembahasan budaya manusia. Namun dalam budaya, terdapat unsur yang sangat melekat yaitu agama.

Salah satu ciri ilmu pengetahuan adalah memiliki metode pendekatan untuk mengkaji suatu obyek. Metode pendekatan hadir sebagai cara pandang sebuah ilmu pengetahuan terhadap suatu masalah. Selain itu, metode pendekatan juga berfungsi untuk membedakan ilmu pengetahuan satu dengan ilmu pengetahuan lainnya. Antropologi sebagai sebuah ilmu pengetahuan pastinya juga memiliki metode pendekatan. Dilansir dari buku Sketsa Dasar Mengenal Manusia dan Masyarakat (2020) karya Gregor Neon basu, dijelaskan bahwa metode pendekatan dalam Ilmu Antropologi dibedakan menjadi dua aliran, yaitu: 


\section{Aliran tradisional}

Ada dua jenis pendekatan dalam aliran tradisional ini, yaitu:

\section{Pendekatan komparatif}

Pendekatan komparatif merupakan pendekatan yang merujuk pada pola perbandingan dengan meletakkan dua hal budaya pada sisi yang sama dan juga menjelaskan sisi-sisi yang berbeda. Pendekatan komparatif merupakan sebuah pendekatan unik didalaman tropologi. Pendekatan ini dipakai buat memahami suatu kebudayaan masyarakat yang masih belum mengenal baca-tulis atau pra-aksara. Para ahli antropologi sangat meyakini bahwa setiap teori perlu diuji sebanyak mungkin pada populasi serta kebudayaan sebelum bida diverifikasi. Ahli antropologi juga merasa jika lebih mudah buat mempelajari kebudayaan pada masyarakat kecil. Dimana relatif sama atau homogen dibandingkan masyarakat modern yang jauh lebih kompleks.

\section{Pendekatan holistis}

merupakan pendekatan secara menyeluruh untuk memperoleh segala hal yang berkaitan dengan manusia. Pendekatan holistis dilakukan dengan memperhatikan keseluruhan aspek sebagai unit yang bersifat fungsional atau sebagai satu sistem yang utuh. Pendekatan ini berusaha mencari jejaring yang mencakup keseluruhan ruang lingkup kehidupan manusia.

\section{Aliran kontemporer}

Ada tiga jenis pendekatan dalam aliran kontemporer, yaitu:

\section{Pendekatan partikularistik}

Pendekatan partikularistik merupakan pendekatan yang berawal dari sesuatu yang terbatas, kemudian menarik kesimpulan untuk sesuatu yang lebih luas dan umum. Dalam pendekatan ini, peneliti berangkat dari sesuatu yang bersifat partikular, kemudian berusaha untuk masuk pada sesuatu yang berlaku umum di mana-mana. Tokoh yang menggunakan pendekatan ini antara lain E.E. Evans Pritchard yang melakukan penelitian kepada Suku Nuer di Afrika Selatan dan Prof. Fox yang melakukan penelitian di Rote, NusaTenggaraTimur

\section{Pendekatan interpretatif}

Pendekatan interpretatif pertama kali dikemukakan oleh Clifford Geertz ketika membuat penelitian tentang islam di Maroko dan Indonesia (Jawa dan Bali). Pendekatan interpretative bersifat humanistic karena seluruh ungkapan dan segala sesuatu yang berhubungan dengan kehidupan setiap subyek manusia selalu menjadi pusat perhatian dengan saksama. Hal tersebut bias terjadi karena pendekatan interpretative dapat 
Menempatkan semua kepentingan masyarakat sebagai kunci dan pokok kajian intelektual. Termasuk juga deskripsi tentang seluruh gejolak spiritual

Pendekatan struktural

Pendekatan struktur adalah pendekatan analisis data dengan memperhatikan elemen-elemen kunci dari berbagai dimensi sekunder dari obyek yang diteliti dengan seimbang.Pendekatan ini pertama kali dikembangkan oleh Prof. Fox.

Metode pendekatan Antropologi hokum seperti:

1. Metode Historis, yaitu mempelajari manusia melalui sejarah. Kebiasaan yang ada dalam masyarakat menjadi adat, kemudian menjadi hukum adat, hukum adat dipertahankan oleh penguasa dan kemudian menjadi hukum negara. Metode Historis mempelajari perilaku manusia dan budaya hukumnya dengan kacamata sejarah. Perkembangan karakteristik budaya merupakan awal budaya masyarakat. Budaya hukum yaitu ide, gagasan, harapan masyarakat terhadap hukum.

2. Metode Normatif Eksploratif, yaitu mempelajari perilaku manusia dan budaya hukum nya melalui norma hukum yang sudah ada/ yang dikehendaki, bukan semata mempelajari norma hukum yang berlaku, tapi melihat perilaku manusia barulah mengetahui hukum yang akan diterapkan

3. Metode Deskriptif Perilaku, yaitu mempelajari prilaku manusia dan budaya hokum nya melalui hukum yang nyata tanpa melihat aturan hukum ideal. Metode ini disertai dengan metode kasus. Metode Deskriptif Perilaku menggambarkan perilaku manusia dan budaya hukumnya termasuk melukiskan/menggambarkan perilaku nyata jika mereka sedang berselisih/bersengketa. (melihat sistemhukum mana yang digunakan (hukum adat atau hukum Negara)

4. Metode Studi Kasus, adalah pendekatan Antropologi Hukum dengan mempelajari kasus-kasus yang terjadi terutama kasus perselisihan. Metode Studi Kasus mempelajari kasus-kasus hukum dan penyelesaiaannya yang berkembang dalam masyarakat dimana penyelesaian sengketa melalui pengadilan merupakan alternative terakhir. Biasanya mempelajari kasus-kasus perselisihan kelompok masyarakat, latar belakang kultur yang menyebabkannya dan rencana solusi penyelesaiannya

5. Metode Ideologis. Metode ini dilakukan untuk penelitian penjajahan dengan mempelajari kaidah-kaidah hukum yang ideal (norma ideal) yang tertulis maupun yang tidak tertulis. Penelitian ini memperoleh prinsip-prinsip hokum dalam kehidupan masyarakat. 


\section{Penutup}

Pengkajian Antropologi Hukum telah memberikan telaah akan hasil kreasi, distribusi dan transmisi hukum yang ada. Kajian mengenai bagaimana kekuasaan hukum berproses dan memberi dampak dalam masing-masing masyarakat. Selanjutnya akan menampilkan bagaimana feedback dan pengaruh masyarakat-masyarakat terhadap kekuasaan hokum tersebut. Kemajemukan hukum yang ada diIndonesia dewasa ini merupakan soal tersendiri mengingat otetisitas Antropologi Hukum yang sejak lama menempatkan dan menghargai the other laws secara proporsional dan kontekstual. Dengan demikian para pengkaji antropologi hokum ditantang untuk memberikan kontribusi bagi perkembangan hukum di Indonesia, khususnya terkait dengan korelasi positif the other laws dengan state laws.

Antropologi Hukum merupakan kajian yang berkaitan dengan norma social seperti hal nya hukum. Jika terjadi sebuah pelanggaran maupun tindakan yang bertentangan terhadap norma social ini akan membuat pelanggar diberikan sanksi. Pembagian obyek kajian antropologi meliputi manusia, kebudayaan dan juga perilakunya. Ini yang membuat obyek antropologi bersangkutan dengan semua manusia kapanpun dan dimanapun. Tujuan antropologi sendiri yaiti buat membangun masyarakat dengan cara mempelajari perilakunya. Perilaku dari beberapa faktor perubahan social bagaimana manusia bisa bermasyarakat dalam suku bangsa dan budaya manusia. Antropologi sendriri sebenarnya ilmu yang memadukan secara integratif serta bertujuan biologi serta sosio-budaya di kehidupan sehari-hari

Pendekatan komparatif merupakan pendekatan yang merujuk pada pola perbandingan dengan meletakkan dua hal budaya pada sisi yang sama dan juga menjelaskan sisi-sisi yang ber beda. Pendekatan komparatif merupakan sebuah pendekatan unik didalam antropologi. Pendekatan ini dipakai buat memahami suatu kebudayaan masyarakat yang masih belum mengenal baca-tulis atau pra-aksara. Para ahli antropologi sangat meyakini bahwa setiap teori perlu diuji sebanyak mungkin pada populasi serta kebudayaan sebelum bida diverifikasi. Ahli antropologi juga merasa jika lebih mudah buat mempelajari kebudayaan pada masyarakat kecil. Dimana relatif sama atau homogen dibandingkan masyarakat modern yang jauh lebih kompleks. 


\section{DAFTAR \\ PUSTAKA}

Darmini Roza dan Laurensius Arliman S, Peran Pemerintah Daerah Di Dalam Melindungi Hak Anak Di Indonesia, Masalah-Masalah Hukum, Volume 47, Nomor 1, 2018. https://doi.org/10.14710/mmh.47.1.2018.10-21

Laurensius Arliman S, Peranan Metodologi Penelitian Hukum di Dalam Perkembangan Ilmu Hukum di Indonesia, Soumatera Law Review, Volume 1, Nomor 1, 201. http://doi.org/10.22216/soumlaw.v1i1.3346.

Laurensius Arliman S, Peran Badan Permusyawaratan Desa di Dalam Pembangunan Desa dan Pengawasan Keuangan Desa, Padjadjaran Journal of Law, Volume 4, Nomor 3, 2017. https://doi.org/10.15408/jch.v4i2.3433.

Laurensius Arliman S, Penanaman Modal Asing Di Sumatera Barat Berdasarkan Undang- Undang Nomor 25 Tahun 2007 Tentang Penanaman Modal, Supremasi Hukum, Volume 1, Nomor 1, 2018. http://dx.doi.org/10.36441/hukum.v1i01.102 .

Laurensius Arliman S, Memperkuat Kearifan Lokal Untuk Menangkal Intoleransi UmatBeragama Di Indonesia, Ensiklopedia of Journal, Volume 1, Nomor 1, 2018, https://doi.org/10.33559/eoj.v1i1.18.

Laurensius Arliman S, Perkawinan Antar Negara Di Indonesia Berdasarkan Hukum Perdata Internasional, Kertha Patrika, Volume 39, Nomor 3, 2017 , https://doi.org/10.24843/KP.2017.v39.i03.p03.

Laurensius Arliman S, Partisipasi Masyarakat Di Dalam Pengelolaan Uang Desa Pasca UndangUndang Nomor 6 Tahun 2014 Tentang Desa, Jurnal Arena Hukum, Volume 12, Nomor 2, 2019, https://doi.org/10.21776/ub.arenahukum.2019.01202.5.

Laurensius Arliman S, Mewujudkan Penegakan Hukum Yang Baik Di Negara Hukum Indonesia, Dialogica Jurnalica, Volume 11, Nomor 1, 2019, https://doi.org/10.28932/di.v11i1.1831.

Laurensius Arliman S, Mediasi Melalui Pendekatan Mufakat Sebagai Lembaga Alternatif Penyelesaian Sengketa Untuk Mendukung Pembangunan Ekonomi Nasional, UIR Law Review, Volume 2, Nomor 2, 2018, (https://doi.org/10.25299/uirlrev.2018.vol2(02).1587

Laurensius Arliman S, Peranan Filsafat Hukum Dalam Perlindungan Hak Anak Yang Berkelanjutan Sebagai Bagian Dari Hak Asasi Manusia, Doctrinal, Volume 1, Nomor 2,2016 .

Laurensius Arliman S, Ni Putu Eka Dewi, Protection of Children and Women's Rights in Indonesiathrough International Regulation Ratification, Journal of Innovation, Creativity and Change Volume 15, Nomor 6, 2021.

Laurensius Arliman S, Gagalnya Perlindungan Anak Sebagai Salah Satu Bagian Dari Hak Asasi Manusia Oleh Orang Tua Ditinjau Dari Mazhab Utilitarianisme, Jurnal Yuridis, Volume 3, Nomor 2, 2016, http://dx.doi.org/10.35586/.v3i2.180.

Laurensius Arliman S, Tantangan Pendidikan Kewarganegaraan Pada Revolusi 4.0, Jurnal Ensiklopedia Sosial Review, Volume 2, Nomor 3, 2020. 